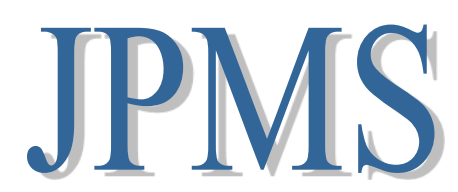

Jurnal Pengabmas Masyarakat Sehat

ARTIKEL HASIL PENGABDIAN KEPADA MASYARAKAT

URL artikel: http://ejournal.poltekkes-denpasar.ac.id/index.php/JPMS/article/view/jpms2404

\title{
Penyuluhan Perdarahan Masa Nifas Pada Kader Di Posyandu Desa Kairatu
}

\author{
Windatani Mayasari ${ }^{1 k}$; Marwia Samal ${ }^{1}$ \\ ${ }^{1}$ Sekolah Tinggi Ilmu Kesehatan Maluku Husada, DIII Kebidanan \\ Email penulis korespondensi $\left({ }^{\mathrm{K}}\right)$ : Mayasari@gmail.com
}

\begin{abstract}
World Health Organization (WHO) data shows that $99 \%$ of maternal deaths due to childbirth or birth problems occur in developing countries. When compared with the ratio of maternal mortality in nine developed countries and 51 Commonwealth countries, the ratio of maternal mortality in developing countries is the highest with 450 maternal deaths per 100 thousand live births. Post-partum bleeding is diagnosed when the amount of bleeding is considered to be more than normal. Clinical signs and symptoms of blood loss include weakness, sweating, and tachycardia which usually occur after the loss of $15-25 \%$ of total blood volume loss. Hemodynamic reduction only occurs in blood loss of $35 \%$ and $45 \%$.
\end{abstract}

Keywords: Posyandu Cadres, Puerperal Bleeding.

\section{Pendahuluan}

Perdarahan post partum adalah perdarahan yang terjadi segera setelah persalinan melebihi $500 \mathrm{cc}$ setelah anak lahir. Perdarahan dapat terjadi sebelum atau sesudah lahirnya plasenta. ${ }^{(1)}$ Data World Health Organization (WHO) menunjukkan sebanyak 99\% kematian ibu akibat masalah persalinan atau kelahiran terjadi di negara-negara berkembang. Jika dibandingkan dengan rasio kematian ibu di sembilan negara maju dan 51 negara persemakmuran rasio kematian ibu di negaranegara berkembang merupakan yang tertinggi dengan 450 kematian ibu per 100 ribu kelahiran bayi hidup. ${ }^{(2)}$

Menurut Profil Kesehatan Indonesia tahun 2014 empat penyebab kematian ibu terbesar yaitu perdarahan 30,3\%, hipertensi dalam kehamilan (HDK) 27,1\%, infeksi 7,3\%, dan lainlain yaitu penyebab kematian ibu tidak langsung seperti kondisi penyakit kanker, ginjal, jantung atau penyakit lain yang diderita ibu sebesar $35,3 \% .^{(3)}$

Pendarahan post-partum didiagnosa apabila jumlah pendarahan dianggap melebihi batas normal. Tanda dan gejala klinis dari kehilangan darah meliputi kelemahan, berkeringat, dan takikardi yang biasanya timbul setelah kehilangan 15-25\% kehilangan darah dari volume total. Penurunan hemodinamik hanya terjadi pada kehilangan darah $35 \%$ dan $45 \% .^{(4)}$ 
Paritas dan umur ibu juga merupakan salah satu faktor pengaruh terjadinya perdarahan postpartum, ibu primigravida dengan usia kurang dari 20 tahun, secara fisik, organ reproduksinya masih berada dalam tahap pertumbuhan dan perkembangan, secara psikologis karena ketidaksiapan ibu usia muda dalam menghadapi persalinan yang pertama, merupakan faktor penyebab ketidak-mampuan ibu dalam menangani komplikasi yang terjadi selama kehamilan, persalinan dan nifas. Usia ibu juga berkaitan dengan ketidakmampuan organ dalam proses reproduksi, wanita di bawah 20 tahun, kondisi kehamilan akan membuat dirinya membagi gizinya untuk pertumbuhan janin dalam kandungan, Sedangkan pada ibu usia 35 tahun atau lebih, organ tubuh mulai menunjukkan pengaruh proses penuaannya, seperti hipertensi dan diabetes yang dapat menghambat masukan makanan janin melalui plasenta. Demikian juga halnya dengan ibu paritas tinggi (lebih dari 3), organ reproduksinya mengalami penurunan fungsi yang dapat mempengaruhi kontraksi uterus, sehingga risiko terjadinya perdarahan pascasalin menjadi lebih besar. ${ }^{(5)}$

Penanganan pasien dengan PPP memiliki dua komponen utama yaitu resusitasi dan pengelolaan perdarahan obstetri yang mungkin disertai syok hipovolemik dan identifikasi serta pengelolaan penyebab dari perdarahan. Keberhasilan pengelolaan perdarahan postpartum mengharuskan kedua komponen secara simultan dan sistematis ditangani. Penggunaan uterotonika (oksitosin saja sebagai pilihan pertama) memainkan peran sentral dalam penatalaksanaan perdarahan postpartum. Pijat rahim disarankan segera setelah diagnosis dan resusitasi cairan kristaloid isotonik juga dianjurkan. Penggunaan asam traneksamat disarankan pada kasus perdarahan yang sulit diatasi atau perdarahan tetap terkait trauma. Jika terdapat perdarahan yang terusmenerus dan sumber perdarahan diketahui, embolisasi arteri uterus harus dipertimbangkan. Jika kala tiga berlangsung lebih dari 30 menit, peregangan tali pusat terkendali dan pemberian oksitosin (10 IU) IV/IM dapat digunakan untuk menangani retensio plasenta. Jika perdarahan berlanjut, meskipun penanganan dengan uterotonika dan intervensi konservatif lainnya telah dilakukan, intervensi bedah harus dilakukan tanpa penundaan lebih lanjut. ${ }^{(6)}$

\section{Metode Pengabdian}

Kegiatan pengabdian kepada masyarakat dilaksanakan di Desa Kairatu, pada bulan Januari 2020. Sasaran dari kegiatan pengabdian masyarakat ini adalah para kader posyandu yang berada di lokasi penelitian. Kegiatan pengabdian ini berupa pemberian penyuluhan perdarahan masa nifas kepada kader menggunakan media leaflet, laptop, LCD, kuesioner dan speaker. Kegiatan pengumpulan data akan dilakukan dengan pre-test dan post-test. Teknik pengumpulan data yang digunakan adalah teknik sampling aksidental yaitu siapa saja yang secara kebetulan bertemu dengan peneliti dapat digunakan sebagai sampel penelitian sesuai dengan kriteria inklusi dan eksklusi. Dalam kegiatan pengabdian masyarakat ini pengolahan dan analisis data menggunakan analisis univariat, hasil kuesioner yang didapatkan akan di tabulasi kemudian di analisis secara manual dan dibuatkan pembahasan. 


\section{Hasil dan Pembahasan}

A. Hasil

\section{Hasil Pre-test dan Post-test Pengetahuan Perdarahan Masa Nifas}

Dari hasil data penelitian menunjukan bahwa adanya peningkatan pengetahuan kader tentang perdarahan masa nifas sebesar $80 \%$. Pengetahuan kader mengenai perdarahan masa nifas yang benar saat pre-test sebesar $40 \%$, setelah dilakukan penyuluhan mengenai perdarahan masa nifas, sampel mendapatkan pemahaman dan pengetahuan sehingga nilai post-test meningkat sebesar $80 \%$. Data selengkapnya dapat dilihat pada tabel 1.

Tabel 1. Hasil Pre-test dan Post-test Pengetahuan Perdarahan Masa Nifas

\begin{tabular}{ccccccc}
\hline \multirow{2}{*}{ No } & \multicolumn{3}{c}{ Pre-test } & \multicolumn{3}{c}{ Post-test } \\
\cline { 2 - 7 } & Pengetahuan & $\mathrm{f}$ & $\%$ & Pengetahuan & $\mathrm{f}$ & $\%$ \\
\hline 1 & Baik & 4 & 40,0 & Baik & 8 & 80,0 \\
2 & Kurang & 6 & 60,0 & Kurang & 2 & 20,0 \\
\hline & Jumlah & 10 & 100,0 & Jumlah & 10 & 100,0 \\
\hline
\end{tabular}

\section{B. Pembahasan}

Pada kegiatan ini rendahnya pengetahuan kader dipengaruhi oleh ketidaktahuan tentang perdarahan masa nifas serta penanganan yang benar. Dalam kegiatan pengabdian ini para kader aktif dalam mengikuti kegiatan penyuluhan dari awal dilaksanakan sampai akhir dilaksanakan. Peserta pengabmas aktif dalam sesi tanya jawab. Kegiatan pengabmas ini selain memberikan penambahan pengetahuan dan wawasan pada kader juga dapat memperbaiki teknik penanganan perdarahan saat masa nifas. Sebelum dilakukan penyuluhan dilakukan pre-test tentang perdarahan masa nifas yang kuesionernya disebarkan oleh mahasiswa lalu dilakukan sesi penyuluhan degan memberikan leaflet lalu memulai materi penyuluhan yang dibawakan oleh mahasiswa. Setelah sesi materi tiba sesi tanya jawab dengan menggunakan metode diskusi aktif yang dijawab oleh dosen. Setelah sesi diskusi mahasiswa menyebar kuesioner kembali untuk melakukan evaluasi pengetahuan pada kader. Kemudian hasil data dibuatkan tabulasi dan dilakukan analisis data menggunakan hitungan manual lalu hasil hitungan manual dideskripsikan. Dengan adanya penyuluhan ini maka pemahaman dan wawasan kader tentang bahaya dan penanganan perdarahan pada masa nifas dapat meningkat.

\section{Simpulan dan Saran}

Berdasarkan kegiatan pengabdian kepada masyarakat ini didapatkan hasil bahwa adanya peningkatan pengetahuan kader tentang pendarahan masa nifas sebesar $80 \%$. Diharapkan dengan kegiatan ini para kader dan tenaga kesehatan rutin melakukan edukasi mengenai perdarahan pada ibu nifas yang diharapkan dapat merubah kebiasaan yang salah menjadi kebiasaan yang benar sehingga angka kematian pada ibu pasca bersalin dengan penyebab perdarahan masa nifas dapat berkurang. 


\section{Daftar Pustaka}

1. Wiknjosastro, H. Ilmu Kebidanan. Jakarta: Yayasan Bina Pustaka Sarwono Prawirohardjo. 2009

2. Kementrian Kesehatan RI. Profil Kesehatan Indonesia Jakarta:; 2011.

3. Kementrian Kesehatan RI. Profil Kesehatan Indonesia, Jakarta.2014

4. M. Walfish, A Neuman, D. Wlody. Maternal hemorrhage. British Journal of Anaesthesia. 2009

5. Moedjiarto, Karakteristik Ibu yang Berhubungan dengan Perdarahan Postpartum. Jurnal Ilmiah Kesehatan.2009

6. Ristanto. Penanganan Perdarahan Pasca Salin. 2013. Tersedia di : http://obginugm.com/wpcontent/uploads/2016/01/PenangananPerdarah-Pascasalin-di-TingkatLayananPrimer.pdf 